\title{
The Effect of Numbered Head Together (NHT) Cooperative Learning Model on Students' Mathematics Learning Outcomes on Collected Materials in Class VII SMP Swasta Jambi Medan
}

\author{
Sanggam P Gultom ${ }^{1}$, Sanhedrin Ginting ${ }^{2}$ dan Alimin Purba ${ }^{2}$ \\ 1.HKBP Nommensen University Medan, Indonesia \\ 2.Darma Agung University Medan, Indonesia
}

\begin{abstract}
This study aims to determine: 1) student learning outcomes before applying the NHT type cooperative learning model in mathematics with Association Materials in Class VII SMP Swasta Jambi Medan, and 2) student learning outcomes after applying the Number Head Together (NHT) type cooperative learning model. in Mathematics with Set Materials in Class VII SMP Swasta Jambi Medan. The type of this research is classroom action research which is conducted in SMP Swasta Jambi Medan Class VII. The findings of this study indicate: (1) in the first cycle, the average score was 68 and as many as 11 students $(36.67 \%)$ had achieved learning mastery while 19 students $(63.33 \%)$ had not achieved learning mastery. In the first cycle, students' learning outcomes were obtained with an average value of 72 with learning completeness reaching $60.00 \%$ or as many as 18 students while 12 students $(40.00 \%)$ had not achieved learning mastery scores. In the second cycle, students' learning outcomes were obtained with an average value of 77 with learning mastery reaching $90.00 \%$ or as many as 27 students while 3 students $(10.00 \%)$ had not achieved learning mastery scores. From the results obtained, that the percentage of mathematics learning outcomes of seventh grade students of SMP Swasta Jambi Medan showed a very significant increase in each cycle.
\end{abstract}

Keywords: Numbered Head Together (NHT) Cooperative Learning Model and Mathematics Learning Outcomes DOI: $10.7176 / \mathrm{JEP} / 13-4-06$

Publication date: February $28^{\text {th }} 2022$

\section{Introduction}

Based on the Laws and Government Regulations of the Republic of Indonesia Article 1 No. 20 of 2003 concerning education states that "education is a conscious and planned effort to create a learning atmosphere and learning process so that students actively develop their potential to have religious spiritual strength, self-control, personality, intelligence, noble character, and the skills they need, society, nation and state".

Education creates change, because it relates to the cultivation of the values of truth, holiness, and the goodness of life for humans. The potential of the nation's children who are able to change the direction of education in Indonesia for the better. Therefore we must know the problems of education today. Among them are problems that exist in teachers and students. Students who don't care about lessons and teachers who are still not right in choosing a learning model.

Education is dynamic in nature which demands a change or continuous improvement in an effort to make quality human beings so that they are able to advance the nation, state and religion. Education that is able to advance the nation, state and religion in the future is education that is able to develop the potential of students.

Mathematics learning activities in schools in Indonesia are still dominated by conventional learning. Students are positioned as objects who are considered not to know anything while teachers are positioned as people who have knowledge, the highest authority so that students do not understand well what they are learning.

Based on the results of initial observations in class VII SMP Swasta Jambi Medan, it appears that learning is still using conventional learning that uses the question and answer method and the assignment method so that it has not been able to optimize student activity. Smart students tend to dominate the teacher's answers to questions and students who are less intelligent and seem passive. Likewise, the method of giving assignments has not been able to balance aspects of the personality of students, for example if given homework assignments only a few people do it, while other students copy the work of their friends. This involves students who are less active in learning activities and mathematics is considered difficult and not understood by students as the results of interviews with SMP Swasta Jambi Medan, some of whom stated that mathematics is difficult to understand.

One of the teaching materials that students feel is still quite difficult to understand is set material, especially in knowing the types of numbers, understanding set notation, reading symbols used as variables, for example $" A=\{x \mid x-520$, x prime numbers $\} "$. Many people view mathematics as the most difficult field of study. Nevertheless, everyone should learn it because it is a means to solve the problems of everyday life. Mathematics is a key part of schooling because of the importance of basic numeracy skills in everyday life, the role of mathematics in acquiring logical thinking skills, and the role of mathematics as a crucial component of other fields of science. 
Based on information from interviews with mathematics teachers at SMP Swasta Jambi Medan, that the mathematics learning outcomes of grade VII students are generally still low, it can be seen that there are still student learning outcomes that do not meet the value requirements set by the teacher in achieving the MCC (Minimum Completeness Criteria). For example, mathematics learning outcomes only get a score of 60, while the MCC standard is 75 so that it affects the average mathematics learning outcomes obtained by students. Meanwhile, learning outcomes are very important in education. Learning outcomes become evidentiary data that will show the level of student ability in achieving learning objectives.

Efforts to obtain good learning outcomes in achieving high-quality education, especially in mathematics, require the role of teachers and students. Teachers occupy a key position in creating a conducive and fun learning atmosphere to direct students to achieve optimal goals, and teachers must be able to position themselves dynamically and flexibly as informants, transformers, organizers, and evaluators for the realization of dynamic and innovative student learning activities. While students in acquiring knowledge do not receive passively, knowledge is built by students themselves actively.

One way to generate active student learning activities and improve student learning outcomes in learning is the use of an appropriate learning model, namely cooperative learning. According to Slavin (1995), there are two reasons, including: 1) several research results prove that the use of cooperative learning can improve student learning outcomes while at the same time increasing social relationship skills, fostering an attitude of acceptance of the shortcomings of self and others, and 2) cooperative learning can realize the needs of students in learning to think, solve problems, and integrate knowledge with skills.

Cooperative learning model has many types. One type of cooperative learning model that researchers consider appropriate in learning mathematics on set material is Numbered Head Together (NHT). Because in studying mathematics, it is not enough just to know and memorize concepts but also requires an ability to solve mathematical problems properly and correctly. In addition, this type of NHT requires students to have an attitude of responsibility, students will be more concerned about their learning outcomes.

Cooperative learning with Numbered Head Together type is a series of material delivery using groups as a forum to unite students' perceptions/thoughts against questions posed by the teacher, which will then be accounted for by students according to the teacher's request number from each group. Thus, in groups of students are given a number according to their respective order.

\section{Research Method}

This type of research is Classroom Action Research (CAR). CAR is marked by an action in an effort to improve the teaching and learning process in the classroom. The subjects in this study were seventh grade students of Jambi Private Junior High School Medan. While the object of this research is the result of students' learning mathematics through the application of cooperative learning type Numbered Head Together (NHT) on the subject of the set.

\section{Results and Discussion}

Data on students' mathematics learning outcomes were taken using a test (evaluation) of learning outcomes. The data on students' mathematics learning outcomes on the set material are shown in the form of Preliminary Test, Test Cycle I and Test Cycle II as follows. 
Table 3.1. Pre-cycle Student Mathematics Learning Outcomes

\begin{tabular}{|c|c|c|c|}
\hline No. & $\begin{array}{c}\text { Student Name } \\
\text { (Initial) }\end{array}$ & Value & Description \\
\hline 1 & $\bar{A}$ & 70 & $\overline{\mathrm{TT}}$ \\
\hline 2 & $\mathrm{~B}$ & 70 & TT \\
\hline 3 & $\bar{C}$ & 75 & $\mathrm{~T}$ \\
\hline 4 & $\bar{D}$ & 75 & $\bar{T}$ \\
\hline 5 & $E$ & 60 & TT \\
\hline 6 & $\bar{F}$ & 75 & $\bar{T}$ \\
\hline 7 & $\bar{G}$ & 75 & $\mathrm{~T}$ \\
\hline 8 & $\mathrm{H}$ & 75 & $\mathrm{~T}$ \\
\hline 9 & $\mathrm{I}$ & 70 & TT \\
\hline 10 & $\overline{\mathrm{J}}$ & 60 & TT \\
\hline 11 & $\bar{K}$ & 85 & $\bar{T}$ \\
\hline 12 & $\mathrm{~L}$ & 70 & TT \\
\hline 13 & $\bar{M}$ & 70 & $\mathrm{TT}$ \\
\hline 14 & $\mathrm{~N}$ & 70 & $\mathrm{TT}$ \\
\hline 15 & $\mathrm{O}$ & 60 & TT \\
\hline 16 & $\mathrm{P}$ & 60 & TT \\
\hline 17 & $\bar{Q}$ & 70 & TT \\
\hline 18 & $\bar{R}$ & 80 & $\overline{\mathrm{T}}$ \\
\hline 19 & $\overline{\mathrm{S}}$ & 70 & TT \\
\hline 20 & $\bar{T}$ & 60 & $\mathrm{TT}$ \\
\hline 21 & $\bar{U}$ & 80 & $\mathrm{~T}$ \\
\hline 22 & $\bar{V}$ & 80 & $\bar{T}$ \\
\hline 23 & $\overline{\mathrm{W}}$ & 60 & $\mathrm{TT}$ \\
\hline 24 & $\mathrm{X}$ & 50 & TT \\
\hline 25 & $\bar{Y}$ & 50 & $\mathrm{TT}$ \\
\hline 26 & $\bar{Z}$ & 75 & $\bar{T}$ \\
\hline 27 & $\overline{\mathrm{AA}}$ & 80 & $\overline{\mathrm{T}}$ \\
\hline 28 & BB & 45 & $\mathrm{TT}$ \\
\hline 29 & $\mathrm{CC}$ & 60 & TT \\
\hline 30 & $\mathrm{DD}$ & 60 & TT \\
\hline \multirow{3}{*}{\multicolumn{3}{|c|}{$\begin{array}{r}\text { Amount } \\
\text { Average } \\
\text { Highest Score }\end{array}$}} & 2040 \\
\hline & & & 68 \\
\hline & & & 85 \\
\hline \multicolumn{3}{|c|}{ Lowest Score } & 45 \\
\hline \multicolumn{3}{|c|}{ Completed Student } & 11 \\
\hline \multicolumn{3}{|c|}{ Students Not Complete } & 19 \\
\hline \multicolumn{3}{|c|}{ Completeness Percentage } & $36,67 \%$ \\
\hline \multicolumn{3}{|c|}{ Percentage of Incompleteness } & $63,33 \%$ \\
\hline
\end{tabular}

Based on Table 3.1. above, shows that students' mathematics learning outcomes before being given action (pre-cycle) are classified as very low, it can be seen that the number of students who do not complete compared to students who complete learning There are 11 students (36.67\%) who finished studying out of 30 students. In this initial test, the students' average score was 68. This is very far from what is expected it is expected that because it does not reach the specified Minimum Criteria Completeness (MCC) value of 75. Then proceed to the next action, namely in the first cycle by applying the NHT type cooperative learning model. 
Table 3.2. Student Mathematics Learning Outcomes in Test Cycle I

\begin{tabular}{|c|c|c|c|}
\hline No. & $\begin{array}{c}\text { Student Name } \\
\text { (Initial) }\end{array}$ & Value & Description \\
\hline 1 & $\mathrm{~A}$ & 75 & $\mathrm{~T}$ \\
\hline 2 & $\mathrm{~B}$ & 75 & $\mathrm{~T}$ \\
\hline 3 & $\mathrm{C}$ & 75 & $\mathrm{~T}$ \\
\hline 4 & $\bar{D}$ & 75 & $\mathrm{~T}$ \\
\hline 5 & $E$ & 65 & $\mathrm{TT}$ \\
\hline 6 & $\mathrm{~F}$ & 75 & $\mathrm{~T}$ \\
\hline 7 & $\mathrm{G}$ & 75 & $\mathrm{~T}$ \\
\hline 8 & $\mathrm{H}$ & 75 & $\mathrm{~T}$ \\
\hline 9 & $\bar{I}$ & 75 & $\mathrm{~T}$ \\
\hline 10 & $\mathbf{J}$ & 75 & $T$ \\
\hline 11 & $\mathrm{~K}$ & 90 & $\mathrm{~T}$ \\
\hline 12 & $\mathrm{~L}$ & 70 & $\mathrm{TT}$ \\
\hline 13 & $\bar{M}$ & 70 & TT \\
\hline 14 & $\mathrm{~N}$ & 70 & TT \\
\hline 15 & $\mathrm{O}$ & 65 & TT \\
\hline 16 & $\mathrm{P}$ & 65 & $\mathrm{TT}$ \\
\hline 17 & $\mathrm{Q}$ & 75 & $\mathrm{~T}$ \\
\hline 18 & $\mathrm{R}$ & 85 & $T$ \\
\hline 19 & $\mathrm{~S}$ & 70 & $\mathrm{TT}$ \\
\hline 20 & $\mathrm{~T}$ & 60 & TT \\
\hline 21 & $\bar{U}$ & 80 & $\mathrm{~T}$ \\
\hline 22 & $\mathrm{~V}$ & 80 & $\bar{T}$ \\
\hline 23 & $\mathrm{~W}$ & 75 & $\bar{T}$ \\
\hline 24 & $\mathrm{X}$ & 55 & $\mathrm{TT}$ \\
\hline 25 & $Y$ & 55 & TT \\
\hline 26 & Z & 75 & $\mathrm{~T}$ \\
\hline 27 & $\mathrm{AA}$ & 80 & $\bar{T}$ \\
\hline 28 & BB & 60 & $\mathrm{TT}$ \\
\hline 29 & $\mathrm{CC}$ & 75 & $\mathrm{~T}$ \\
\hline 30 & DD & 70 & TT \\
\hline \multirow{3}{*}{\multicolumn{3}{|c|}{$\begin{array}{r}\text { Amount } \\
\text { Average } \\
\text { Highest Score }\end{array}$}} & 2165 \\
\hline & & & 72 \\
\hline & & & 90 \\
\hline \multicolumn{3}{|c|}{ Lowest Score } & 55 \\
\hline \multicolumn{3}{|c|}{ Completed Student } & 18 \\
\hline \multicolumn{3}{|c|}{ Students Not Complete } & 12 \\
\hline \multicolumn{3}{|c|}{ Completeness Percentage } & $60.00 \%$ \\
\hline \multicolumn{3}{|c|}{ Percentage of Incompleteness } & $40.00 \%$ \\
\hline
\end{tabular}

Based on Table 3.2. above, it is known that the average score of learning outcomes in the first cycle has reached 72 , but has not reached classical learning completeness because what is obtained is only $60.00 \%$. This shows that 18 students who finished studying and achieved the Minimum Completeness Criteria (KKM) while 12 other students $(40.00 \%)$ had not yet achieved complete learning. Therefore, efforts to improve student learning outcomes must be continued in the next action, namely in Cycle II also by applying Numbered Head Together (NHT) cooperative learning. 
Table 3.3 Student Mathematics Learning Outcomes in Test Cycle II

\begin{tabular}{|c|c|c|c|}
\hline No. & $\begin{array}{c}\text { Student Name } \\
\text { (Initial) }\end{array}$ & Value & Description \\
\hline 1 & $\mathrm{~A}$ & 75 & $\mathrm{~T}$ \\
\hline 2 & $\bar{B}$ & 75 & $\bar{T}$ \\
\hline 3 & $\mathrm{C}$ & 75 & $\mathrm{~T}$ \\
\hline 4 & $\bar{D}$ & 75 & $\overline{\mathrm{T}}$ \\
\hline 5 & $\bar{E}$ & 75 & $\overline{\mathrm{T}}$ \\
\hline 6 & $\mathrm{~F}$ & 75 & $\mathrm{~T}$ \\
\hline 7 & $\bar{G}$ & 85 & $\overline{\mathrm{T}}$ \\
\hline 8 & $\mathrm{H}$ & 75 & $\mathrm{~T}$ \\
\hline 9 & $\mathrm{I}$ & 75 & $\mathrm{~T}$ \\
\hline 10 & $\mathbf{J}$ & 75 & $\mathrm{~T}$ \\
\hline 11 & $\overline{\mathrm{K}}$ & 95 & $\mathrm{~T}$ \\
\hline 12 & $\mathrm{~L}$ & 80 & $\mathrm{~T}$ \\
\hline 13 & $\mathrm{M}$ & 75 & $\mathrm{~T}$ \\
\hline 14 & $\mathrm{~N}$ & 75 & $\bar{T}$ \\
\hline 15 & $\mathrm{O}$ & 75 & $\mathrm{~T}$ \\
\hline 16 & $\bar{P}$ & 75 & $\mathrm{~T}$ \\
\hline 17 & $\mathrm{Q}$ & 75 & $\mathrm{~T}$ \\
\hline 18 & $\mathrm{R}$ & 90 & $\mathrm{~T}$ \\
\hline 19 & $\mathrm{~S}$ & 75 & $\mathrm{~T}$ \\
\hline 20 & $\mathrm{~T}$ & 75 & $\mathrm{~T}$ \\
\hline 21 & $\bar{U}$ & 80 & $\mathrm{~T}$ \\
\hline 22 & $\overline{\mathrm{V}}$ & 80 & $\bar{T}$ \\
\hline 23 & $\bar{W}$ & 75 & $\mathrm{~T}$ \\
\hline 24 & $\mathrm{X}$ & 70 & TT \\
\hline 25 & $\bar{Y}$ & 70 & TT \\
\hline 26 & $\bar{Z}$ & 75 & $\mathrm{~T}$ \\
\hline 27 & AA & 85 & $\mathrm{~T}$ \\
\hline 28 & $\mathrm{BB}$ & 65 & TT \\
\hline 29 & $\mathrm{CC}$ & 75 & $\mathrm{~T}$ \\
\hline 30 & $\mathrm{DD}$ & 75 & $\mathrm{~T}$ \\
\hline \multirow{3}{*}{\multicolumn{3}{|c|}{$\begin{array}{r}\text { Amount } \\
\text { Average } \\
\text { Highest Score }\end{array}$}} & 2300 \\
\hline & & & 77 \\
\hline & & & 95 \\
\hline \multicolumn{3}{|c|}{ Lowest Score } & 65 \\
\hline \multicolumn{3}{|c|}{ Completed Student } & 27 \\
\hline \multicolumn{3}{|c|}{ Students Not Complete } & 3 \\
\hline \multicolumn{3}{|c|}{ Completeness Percentage } & $90.00 \%$ \\
\hline \multicolumn{3}{|c|}{ Percentage of Incompleteness } & $10.00 \%$ \\
\hline
\end{tabular}

Based on Table 3.3. above, shows an increase in students' mathematics learning outcomes from the previous meeting. The average score of students is 77 and has achieved learning mastery of $90 \%$ or as many as 27 students out of 30 students. In connection with the achievement of the target in the study, so that the next cycle was stopped.

The data recapitulation of students' mathematics learning outcomes in each cycle can be seen in Table 3.4. below this. 
Table 3.4. Recapitulation of Students' Mathematics Learning Results

\begin{tabular}{|c|l|c|c|c|}
\hline No & \multicolumn{1}{|c|}{ Data } & Pre Cycle & Test Cycle I & Test Cycle II \\
\hline 1 & Complete individually & 11 & 18 & 27 \\
\hline 2 & Not completed individually & 19 & 12 & 3 \\
\hline 3 & Maximum Score & 85 & 90 & 95 \\
\hline 4 & Minimum Score & 45 & 55 & 65 \\
\hline 5 & Total Value & 2040 & 2165 & 2300 \\
\hline 6 & Average & 68 & 72 & 77 \\
\hline 7 & Completeness & $36,67 \%$ & $60,00 \%$ & $90,00 \%$ \\
\hline
\end{tabular}

Based on Table 3.4. above, it can be seen clearly the difference in the improvement of students' mathematics learning outcomes at each meeting. The number of students who completed learning started from 11 people after being given action in Cycle I, 18 students who completed learning were obtained until it was continued with the action in Cycle II with the number of students who completed learning as many as 27 people out of 30 students. The completeness of student learning outcomes is provided by the KKM score of 75. Students who get test results 75 are declared to have achieved learning mastery. For more details, this can be seen in Fig. 3.1. below this.

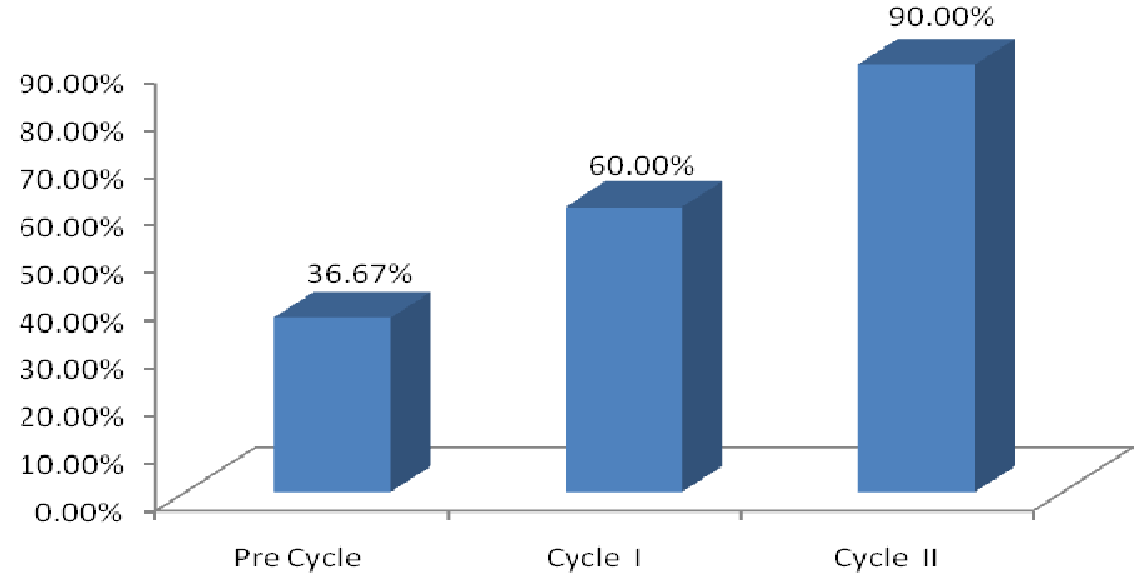

Fig. 3.1. Graph of the Percentage of Completion of Students' Mathematics Learning Outcomes

Based on Fig. 3.1. above, it can be seen that the percentage of mathematics learning outcomes of seventh grade students of Jambi Private Junior High School showed a very significant increase in each cycle.

\section{Conclusion}

Based on the results of the analysis of several cycles and discussions, it can be concluded that:

1. The results of the initial test before being given action using the Numbered Head Together (NHT) cooperative learning model, the average value of students is 68 with a percentage value of classical completeness that is $36.67 \%$ or as many as 11 students while 19 other students are not complete in learning. From these data, the mathematics learning outcomes of seventh grade students of Jambi Private Junior High School are low and cannot be said to be complete because the percentage of classical completeness has not reached $85 \%$.

2. The results of the test in the first cycle using the Numbered Head Together (NHT) cooperative learning model obtained an average value of 72 students with a classical completeness percentage value of $60.00 \%$ or as many as 18 students while the other 12 students did not complete learning. From these data, the mathematics learning outcomes of seventh grade students of Jambi Private Junior High School are low and cannot be said to be complete because the percentage of classical completeness has not reached $85 \%$.

3. The results of the test in the second cycle using the Numbered Head Together (NHT) cooperative learning model, the average value of the students is 77 with the percentage value of classical completeness that is $90.00 \%$ or as many as 27 students while the other 3 students are not complete in learning. From these data, the mathematics learning outcomes of seventh grade students of Jambi Private Junior High School can be said to be complete because the percentage of classical completeness has reached above $85 \%$, which is $90.00 \%$. 


\section{Bibliography}

Arikunto, Suharsimi. et al., 2009. Classroom Action Research. Jakarta: Earth Literacy.

Asrul. et al., 2015. Evaluation of Learning. Medan: Citapustaka Media.

B. Uno, Hamzah. 2014. Learning with PAIKEM Approach. Jakarta: Earth Literacy.

Basrowi and Kelvin. 2008. Classroom Action Research Procedures. Bogor: Ghli Indonesia.

Djamarah, S. B. and Zain, Aswan. 2013. Teaching and Learning Strategy. Jakarta: Rineka Cipta.

Hamalik, Omar. 2010. Teaching and Learning Process. Jakarta: Earth Literacy.

Hamza, Ali and Mushlisraini. 2014. Planning and Strategy for Mathematics Learning. Jakarta: Rajawali Press.

Istarani. 2012. 58 Innovative Learning Models. Medan: Persada Media.

Lee, Anita. 2004. Cooperative Learning. Jakarta: PT. Grasindo.

Mardianto. 2014. Learning Psychology. Medan: Perdana Publishing.

Muijs, Danial and Reynolds, David. 2008. Effective Teaching Theory and Application. Yogyakarta: Student Library.

Ngalimun. 2013. Strategies and learning models. Yogyakarta: Aswaja Pressindo.

Nuharini, Dewi and Wahyuni, Tri. 2008. Mathematical Concepts and Applications. Jakarta: Book Center

Pujihartini. 2013. Classroom Action Research in Middle School Integrative Thematic Learning. Bandung: Science and Technology Forum.

Ruhlat. 2014. Effective Learning Model for Creative Teachers. Bandung: Gaza Publishing.

Rusman. 2012. Learning Models to Develop Teacher Professionalism. Jakarta: Rajagrafindo Persada.

Sanjaya, Wina. 2011. Educational Process Standard Oriented Learning Strategy. Jakarta: Kencana.

Sanjaya, Wina. 2014. Learning Communication Media. Jakarta: Kencana.

Sardiman. 2011. Teaching and Learning Interaction and Motivation. Jakarta: Rajawali Press.

Slameto. 2010. Learning and the factors that influence it. Jakarta: Rineka Cipta.

Sudjana, Nana. 2005. Assessment of Teaching and Learning Outcomes. Bandung: Rosdakarya.

Suprijono, Agus. 2010. Cooperative Learning Theory dan Application of Paikem. Yogyakarta: Student Library.

Susanto, Ahmad. 2013. Theory of Learning and Learning in Elementary Schools. Jakarta: Kencana prenada media group.

Syafaruddin and Nurmawati. 2011. Education Management Developing Education Management Skills Towards Effective Schools. Medan: Perdana Publishing.

Shah, Muhibbin. 2011. Learning Psychology. Jakarta: Rajagrafindo Persada. 